\title{
INSOMNIA PADA PENDERITA KANKER PAYUDARA YANG SEDANG MENJALANI KEMOTERAPI
}

\author{
Rohadatul Aisy ${ }^{1 a}$, Endang Sawitri ${ }^{2 b}$, Denny J. Rotinsulu ${ }^{3 c}$ \\ ${ }^{1}$ Program Studi Kedokteran, Fakultas Kedokteran Universitas Mulawarman \\ ${ }^{2}$ Laboratorium Fisiologi, Fakultas Kedokteran Universitas Mulawarman \\ ${ }^{3}$ Laboratorium Kedokteran Jiwa, Fakultas Kedokteran Universitas Mulawarman \\ arohadatulaisy.ra@gmail.com \\ bendangsawitri68@gmail.com \\ 'dennyjeffry@gmail.com
}

\begin{abstract}
ABSTRAK
Insomnia sering dialami oleh penderita kanker payudara, salah satu penyebabnya adalah kemoterapi yang dijalani oleh penderita. Penelitian ini bertujuan untuk mengetahui gambaran insomnia pada perempuan penderita kanker payudara yang sedang menjalani kemoterapi di RSUD Abdul Wahab Sjahranie Samarinda bulan Juli 2019. Penelitian observasional deskriptif dengan desain cross sectional pada 40 sampel dari 54 penderita yang diinklusi, dan data dianalisis secara univariat. Hasil penelitian menunjukkan bahwa $52 \%$ responden mengalami insomnia, dengan usia $<50$ tahun mengalami insomnia $50 \%$; sedangkan pada usia $\geq 50$ tahun, $62,5 \%$ responden mengalami insomnia. 58\% yang tidak bekerja mengalami insomnia, sedangkan yang bekerja 33\% mengalami insomnia. Seluruhnya sudah menikah dengan $52,5 \%$ mengalami insomnia. Insomnia diderita $56 \%$ responden yang tidak mengalami nyeri, $44 \%$ dengan nyeri lokal, dan $67 \%$ nyeri neuropatik. Sebanyak $80 \%$ responden memiliki $>1$ jenis keluhan insomnia, sedangkan $20 \%$ lainnya memiliki keluhan insomnia tunggal dengan $10 \%$ sleep onset insomnia; $5 \%$ sleep maintenance insomnia; dan 5\% early morning awakening. 48\% mengalami insomnia ringan, 38\% insomnia sedang, dan $13 \%$ insomnia berat. Disimpulkan bahwa penderita kanker payudara yang sedang menjalani kemoterapi di RSUD Abdul Wahab Sjahranie Samarinda pada Juli 2019 sebagian besar mengalami insomnia berusia $\geq 50$ tahun, tidak memiliki pekerjaan, seluruhnya sudah menikah, memiliki insomnia ringan dengan lebih dari 1 jenis keluhan insomnia, serta dialami oleh yang tidak memiliki keluhan nyeri maupun memiliki keluhan nyeri neuropatik.
\end{abstract}

Kata Kunci : Insomnia, kanker payudara, kemoterapi.

*Corresponding Author :

Rohadatul Aisy

Program Studi Kedokteran, Fakultas Kedokteran

Universitas Mulawarman

Email : Rohadatul Aisy@gmail.com 


\section{PENDAHULUAN}

Insomnia merupakan salah satu ganggguan tidur yang paling sering dikeluhkan. Insomnia dapat ditandai dengan kesulitan memulai tidur, kesulitan mempertahankan tidur, maupun terbangun terlalu cepat di pagi hari. Gangguan ini dapat menyebabkan ketidakpuasan terhadap kuantitas dan kualitas tidur dan dapat bersifat sementara ataupun menetap (Sadock, Samoon \& Sadock, 2019).

Peltzer dan Pengpid (2019) melaporkan prevelansi insomnia pada masyarakat usia 15 tahun ke atas di Indonesia pada tahun 2019, bahwa $33,3 \%$ partisipan memiliki sub-threshold insomnia dan 11\% lainnya memiliki insomnia yang terlihat signifikan secara klinis.

Periode singkat insomnia paling sering disebabkan ansietas, baik sebagai gejala sisa suatu pengalaman yang mencemaskan atau sebagai suatu bentuk antisipasi (Sadock \& Sadock, 2017). Pasien kanker sering mengalami gangguan tidur, terutama insomnia. Pola tidur pasien kanker dapat terganggu karena sakit fisik akibat kanker, nyeri, efek samping obat- obatan atau terapi kanker lainnya (misal mual, muntah, diare), lingkungan (suhu dan kebisingan ruangan), gaya hidup (pola makan, olah raga, rutinitas tidur, kondisi emosional), dan dampak psikologis dari kanker (Hananta et al. 2014).

Kanker payudara adalah keganasan pada jaringan payudara yang dapat berasal dari epitel duktus maupun lobulusnya dan merupakan salah satu jenis kanker terbanyak di Indonesia (Komisi Penanggulangan Kanker Nasional [KPKN], 2017). Secara global, kanker payudara menyebabkan angka kematian tertinggi untuk perempuan dan

\section{*Corresponding Author :}

Rohadatul Aisy

Program Studi Kedokteran, Fakultas Kedokteran

Universitas Mulawarman

Email : Rohadatul Aisy@gmail.com epidemiologinya menyebar merata tanpa terkendali (Hananta et al., 2014). Kanker payudara setiap tahunnya terjadi pada 2,1 juta perempuan di seluruh dunia, dan dilaporkan kira-kira terdapat 627.000 perempuan meninggal akibat kanker payudara atau setara 15\% kematian perempuan akibat kanker (World Health Organization [WHO], 2018). Direktur Jendral Pencegahan dan Pengendalian Penyakit Kementerian Kesehatan Republik Indonesia melaporkan bahwa pada tahun 2017 telah terdeteksi 3,1 juta perempuan yang mengalami kanker payudara (Kemenkes RI, 2018).

Salah satu terapi kanker adalah kemoterapi (sering disebut "kemo"). Penelitian Hananta et al. (2014) di Rumah Sakit Dharmais Jakarta, melaporkan persentase gangguan tidur yang dialami penderita kanker payudara sebesar $67,1 \%$ atau 49 orang dari 73 responden, dengan 41 dari 49 penderita tersebut sedang menjalani kemoterapi. Penelitian lain dari Krisdhiyanti (2016) yang dikutip oleh Alifiyanti (2017) mengenai kualitas tidur pada pasien kanker payudara yang sedang menjalani kemoterapi di RSUP dr. Hasan Sadikin (RSHS) Bandung melaporkan bahwa dari 83 pasien yang menjalani kemoterapi, sebanyak 69 (83,13\%) pasien memiliki kualitas tidur buruk, dan jenis gangguan tidur yang paling banyak dialami adalah insomnia $(66,67 \%)$. Gangguan tidur ini, dapat mempengaruhi kualitas hidup pasien, sistem kekebalan tubuh, kemampuan kognitif, dan kemampuan untuk melakukan kegiatan sehari-hari (Hananta et al., 2014). Insomnia pada penderita kanker payudara yang menjalani kemoterapi di RSUD Abdul Wahab 
Sjahranie belum diteliti, sehingga peneliti tertarik untuk menelitinya.

\section{METODE PENELITIAN}

Penelitian deskriptif observasional dengan desain cross sectional ini bertujuan penelitian ini untuk mengetahui gambaran insomnia pada perempuan penderita kanker payudara yang sedang menjalani kemoterapi di RSUD Abdul Wahab Sjahranie bulan Juli tahun 2019. Pengambilan sampel menggunakan teknik purposive sampling. Data primer yang didapatkan dari hasil wawancara responden dengan formulir biodata, kuesioner ID Pain yang dikutip dari Yudiyanta (2017), dan kuesioner KSPBJ-IRS (Kelompok Studi Psikiatri Biologik Jakarta-Insomnia Rating Scale) dikutip dari Pratiwi (2016) yang dianalisis secara univariat, yang ditampilkan dalam bentuk tabel, grafik dan narasi.

\section{HASIL DAN PEMBAHASAN}

Hasil penelitian menemukan bahwa pada bulan Juli 2019 di RSUD Abdul Wahab Sjahranie Samarinda terdapat 54 perempuan penderita kanker payudara yang sedang menjalani kemoterapi, dan dari jumlah penderita tersebut, 14 penderita dieksklusi karena mengalami insomnia sebelum kemoterapi, menggunakan substansi yang menyebabkan gejala yang mirip dengan insomnia, dan tidak bersedia menjadi responden. Dengan demikian terdapat 40 responden yang memenuhi kriteria inklusi.

\section{a. Distribusi Insomnia pada Perempuan Penderita Kanker Payudara yang Sedang Menjalani Kemoterapi}

\section{*Corresponding Author :}

Rohadatul Aisy

Program Studi Kedokteran, Fakultas Kedokteran

Universitas Mulawarman

Email : Rohadatul Aisy@gmail.com

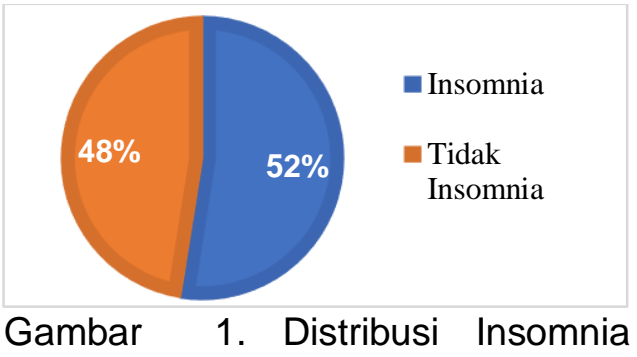

secara Umum pada Penderita Kanker Payudara yang Sedang Menjalani Kemoterapi di RSUD Abdul Wahab Sjahranie Bulan Juli 2019

Gambar 1 memperlihatkan bahwa sebagian besar responden mengalami insomnia (52\%). Hasil ini sesuai dengan penelitian Fakih et al. (2018) pada penderita kanker payudara stadium I-III yang mendapatkan kemoterapi di American University of Beirut Medical Center dimana insomnia lebih banyak dirasakan penderita saat sedang menjalani kemoterapi $(58,3 \%)$ dibandingkan dengan sebelum dan sesudah kemoterapi. Penelitian Costa et al. (2014) pada 12 artikel mengenai gangguan tidur penderita kanker payudara juga menyebutkan bahwa kecenderungan terjadinya gangguan tidur lebih besar pada perempuan yang menjalani kemoterapi.

McGinty, et al. (2017) menyatakan bahwa insomnia dan gangguan tidur yang lain merupakan salah satu masalah yang paling banyak terjadi pada pasien kanker selain nyeri, anoreksia, kelelahan, dan merasa lemas. Insomnia saat menjalani kemoterapi paling banyak dikeluhkan oleh penderita kanker payudara dibanding penderita kanker lain. Efek samping kemoterapi seperti efek agen toksik yang menumpuk, dampak fisik (mual, muntah, diare, peningkatan frekuensi berkemih, atau reaksi kulit), perubahan body 
image, dan kondisi komorbid lain (nyeri, kelelahan, depresi, dan kecemasan), serta perubahan hormonal akibat kemoterapi dapat menyebabkan gejala menopause seperti hot flashes dan keringat malam merupakan faktor-faktor yang menyebabkan maupun memperburuk gangguan tidur penderita (Costa et al., 2014; McGinty, et al., 2017; Paul \& Anafi, 2017).

\section{b. Distribusi Insomnia pada Perempuan Penderita Kanker Payudara yang Sedang Menjalani Kemoterapi berdasarkan Usia}

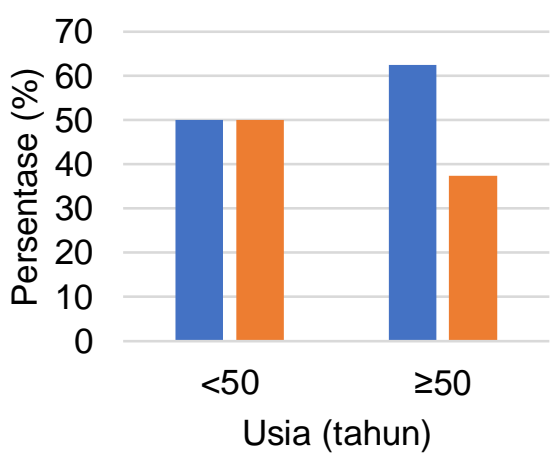

- Insomnia $\quad$ Tidak insomnia

Gambar 2. Distribusi Insomnia pada Penderita Kanker Payudara yang Sedang Menjalani Kemoterapi berdasarkan Usia di RSUD Abdul Wahab Sjahranie Bulan Juli 2019

Gambar 2 memperlihatkan responden yang mengalami insomnia paling banyak terdapat pada usia $\geq 50$ tahun yaitu berjumlah $(62,5,5 \%)$. Hal ini sejalan dengan penelitian oleh Fang, et al. (2015) yang mengambil data pasien kanker dari National Health Insurace Research Database (NHIRD) bahwa gangguan tidur paling banyak ditemukan pada usia $\geq 65$ tahun. Silvestri (2017) menyebutkan bahwa

*Corresponding Author :

Rohadatul Aisy

Program Studi Kedokteran, Fakultas Kedokteran Universitas Mulawarman

Email : Rohadatul Aisy@gmail.com kejadian insomnia lebih banyak pada wanita usia lanjut dibandingkan dengan laki-laki, dimana terjadi peningkatan rasio dari 1,28 pada usia dewasa muda (15-30 tahun) menjadi 1,78 pada usia di atas 65 tahun.

Usia hanya berkontribusi dalam memperparah insomnia yang sebagian besar dipredisposisi oleh hal-hal lain seperti penurunan aktifitas, masalah sosial, maupun penyakit yang sedang dialami. Perubahan dari tidur biasanya lebih berhubungan dengan berbagai kondisi medis dan psikiatri komorbid yang prevelansinya meningkat karena usia. Insomnia yang dialami dapat disebabkan oleh gejala dari penyakit itu sendiri (seperti nyeri), dari efek samping pengobatan (seperti mual, muntah, diare, peningkatan frekuensi berkemih, atau reaksi kulit), maupun dari kecemasan yang dialami akibat penyakit tersebut (Costa et al., 2014; Grewal \& Doghramji, 2017; Paul \& Anafi, 2017).

\section{c. Distribusi Insomnia pada Perempuan Penderita Kanker Payudara yang Sedang Menjalani Kemoterapi berdasarkan Status Pekerjaan}

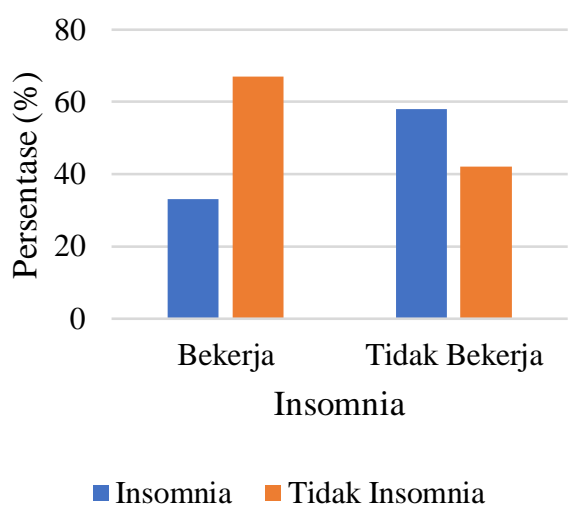

Gambar 3. Distribusi Insomnia pada Penderita Kanker Payudara yang Sedang Menjalani Kemoterapi berdasarkan Status Pekerjaan di 
RSUD Abdul Wahab Sjahranie Bulan Juli 2019

Gambar 3 menunjukkan bahwa insomnia paling banyak terjadi pada responden yang tidak memiliki pekerjaan (58\%). Hasil ini sejalan dengan teori yang menyatakan bahwa terdapat hubungan langsung antara pengangguran, status sosioekonomi yang rendah, dan tingkat pendidikan yang rendah dengan peningkatan prevelansi insomnia (Grewal \& Doghramji, 2017). Maeda et al. (2019) menyebutkan bahwa kelompok dengan pendapatan rendah memiliki prevelansi insomnia lebih besar daripada kelompok dengan pendapatan yang lebih tinggi. Status pekerjaan sangat berpengaruh kepada pendapatan seseorang. Seseorang yang tidak memiliki pekerjaan memiliki risiko gangguan tidur lebih besar dikarenakan kesehatan fisik dan mentalnya yang kurang baik dan keadaan sekitar yang menyebabkan tertekan (kesulitan mencari pekerjaan dan masalah keuangan).

$$
\text { Deguchi et al. (2017) }
$$

menyatakan bahwa insomnia dapat terjadi pada seseorang yang bekerja dikarenakan adanya role conflict. Role conflict adalah situasi dimana pekerja mendapatkan banyak tekanan dari tuntutan pekerjaan yang tidak cocok seperti beban kerja, ketergantungan kelompok, dan perbedaan gaya kerja. Batas antara jam kerja dan waktu pribadi yang ambigu ini menyebabkan keseimbangan antara jam kerja dan kehidupan menjadi buruk dan tekanan fisik maupun psikologis pekerja juga meningkat.

\section{d. Distribusi Insomnia pada Perempuan Penderita Kanker Payudara yang Sedang}

*Corresponding Author :

Rohadatul Aisy

Program Studi Kedokteran, Fakultas Kedokteran

Universitas Mulawarman

Email : Rohadatul Aisy@gmail.com

\section{Menjalani Kemoterapi berdasarkan Status Marital}

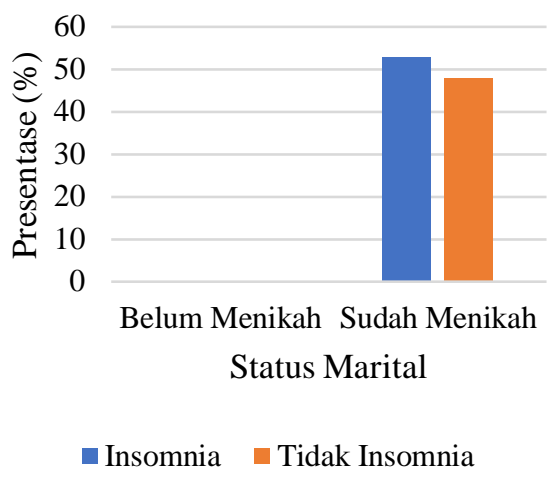

Gambar 4. Distribusi Insomnia pada Penderita Kanker Payudara yang Sedang Menjalani Kemoterapi berdasarkan Status Marital di RSUD Abdul Wahab Sjahranie Bulan Juli 2019

Gambar 4 menggambarkan bahwa seluruh responden dengan status sudah menikah, sebagian besar mengalami insomnia berjumlah 21 orang $(52,5 \%)$. Hasil ini tidak sesuai dengan teori Pigeon \& Grandner (2013) yang menyatakan bahwa status marital merupakan salah satu komponen dari lingkungan tidur yang penting. Teori ini menyatakan bahwa individu yang sudah menikah secara garis besar memiliki kualitas tidur yang lebih baik daripada yang belum menikah.

Namun, hal ini sejalan dengan penelitian Kumar, et al. (2018) dimana penderita yang sudah menikah memiliki risiko mengalami insomnia lebih besar dibandingkan yang belum menikah. Hal ini dapat dipengaruhi oleh kualitas hubungan yang dimiliki oleh responden. Kualitas hubungan responden yang tidak baik dapat memperberat stres atau kecemasan responden yang kemungkinan telah didapatkan dari awal didiagnosis penyakit sampai proses pengobatan kanker payudara. Tidur responden juga dapat 
terganggu apabila responden memiliki anak yang masih usia belia dan sering terbangun di malam hari.

\section{e. Distribusi Insomnia berdasarkan Tingkat Keparahan pada Perempuan Penderita Kanker Payudara yang Sedang Menjalani Kemoterapi}

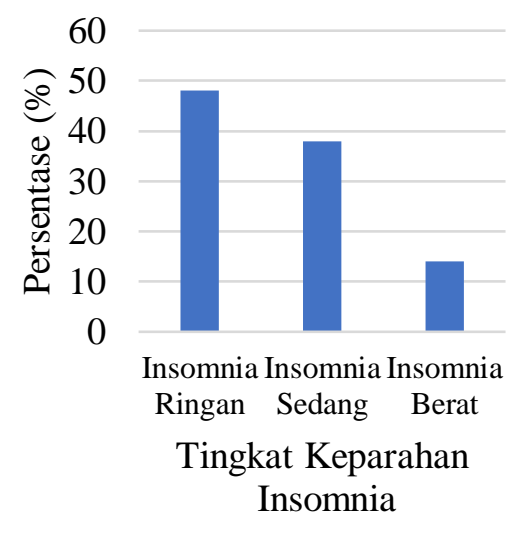

Gambar 7 Distribusi Insomnia berdasarkan Tingkat Keparahan pada Penderita Kanker Payudara yang Sedang Menjalani Kemoterapi di RSUD Abdul Wahab Sjahranie Bulan Juli 2019

Gambar 7 menjelaskan bahwa sebagian besar responden mengalami keluhan insomnia ringan (48\%). Hasil ini tidak sesuai dengan penelitian oleh Hoang, et al. (2019) pada penderita kanker payudara di 3 Rumah Sakit Kanker di Hanoi Vietnam, dimana didapatkan sebagian besar penderita kanker yang menjalani kemoterapi mengeluhkan insomnia sedang $(68,1 \%)$. Perbedaan ini dapat dipengaruhi oleh gejala lain seperti ada atau tidaknya kecemasan dan depresi pada responden.

Adanya depresi dan kecemasan menyebabkan tingkat insomnia lebih tinggi dibandingkan dengan yang tidak memiliki keluhan depresi dan kecemasan. Kecemasan akan

\section{*Corresponding Author :}

Rohadatul Aisy

Program Studi Kedokteran, Fakultas Kedokteran

Universitas Mulawarman

Email : Rohadatul Aisy@gmail.com menyebabkan kesulitan untuk tidur dan meningkatkan kemungkinan mimpi buruk. Selain itu, depresi yang dialami dapat menyebabkan kesulitan mempertahankan tidur, kemungkinan bangun lebih awal, dan mimpi buruk. Sehingga, tingkat keparahan insomnia yang terjadi pada pasien kanker payudara tidak hanya bergantung pada karakteristik kanker dan proses pengobatan, namun juga dapat disebabkan oleh gejala lain yang memperberat kualitas tidur (Mercadante, Girelli, \& Casuccio, 2004; Berk, 2009; Hoang et al., 2019).

Selain kecemasan dan depresi, terdapat beberapa faktor lain yang dapat mempengaruhi kualitas tidur dari responden seperti usia, ada atau tidaknya nyeri yang dirasakan, dan lingkungan tempat responden melaksanakan pengobatan kemoterapi. Faktor-faktor lingkungan seperti suara, cahaya, temperatur, keadaan barang elektronik atau komunikasi, dan barang-barang yang diperlukan untuk tidur (bantal, guling, selimut, dan lain lain) dalam ruangan dapat mempengaruhi kualitas tidur seseorang. Kualitas tidur individu (terutama dengan kondisi medis tertentu) sangat dipengaruhi oleh rasa nyaman yang dirasakan pada tempat individu tersebut beristirahat (Taylor et al., 2014).

f. Distribusi Insomnia berdasarkan Cara Mempengaruhi Tidur pada Perempuan Penderita Kanker Payudara yang Sedang Menjalani Kemoterapi 


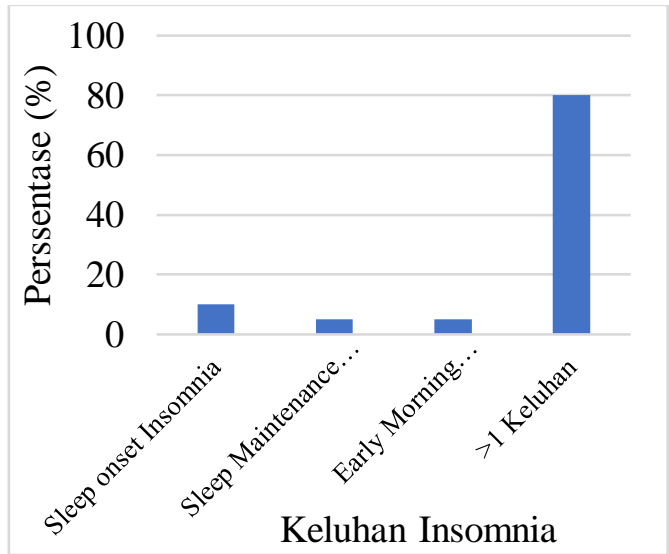

Gambar 6. Distribusi Insomnia berdasarkan Cara Mempengaruhi Tidur pada Penderita Kanker Payudara yang Sedang Menjalani Kemoterapi di RSUD Abdul Wahab Sjahranie Bulan Juli 2019

Gambar 6 menunjukkan bahwa
sebagian besar responden
mengalami lebih dari 1 keluhan insomnia (80\%). Responden yang mengalami keluhan tunggal terbanyak adalah responden yang mengalami keluhan sleep onset insomnia (10\%). Hal ini tidak sesuai dengan penelitian Bragantini et al. (2019) pada responden yang mengalami gangguan tidur, dimana responden dengan keluhan insomnia tunggal $(58 \%)$ lebih banyak dari responden dengan keluhan campuran (42\%) dengan keluhan tunggal terbanyak yang dialami adalah sleep maintenance insomnia (30\%).

Keluhan insomnia terbagi atas sleep onset insomnia, sleep maintenance insomnia, dan early morning awakenings, Namun, beberapa orang dapat mengalami kombinasi dari keluhan insomnia ini (Riemann et al., 2015). Perbedaan ini mungkin berkaitan dengan genetik dan profil biologis seseorang (Lind \& Gehrman, 2016). Efek genetik pada insomnia dapat dipengaruhi oleh

\section{*Corresponding Author :}

Rohadatul Aisy

Program Studi Kedokteran, Fakultas Kedokteran

Universitas Mulawarman

Email : Rohadatul Aisy@gmail.com faktor lingkungan seperti paparan blue light, penggunaan kafein, stres, shift kerja, dan hal lainnya (Bragantini et al., 2019).

\section{g. Distribusi Insomnia pada Perempuan Penderita Kanker Payudara yang Sedang Menjalani Kemoterapi berdasarkan Keluhan Nyeri}

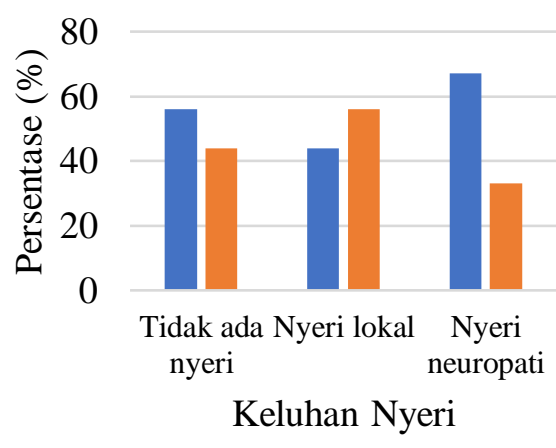

- Insomnia $\quad$ Tidak Insomnia

Gambar 5. Distribusi Insomnia pada Penderita Kanker Payudara yang Sedang Menjalani Kemoterapi berdasarkan Keluhan Nyeri di RSUD Abdul Wahab Sjahranie Bulan Juli 2019

Gambar 5 memperlihatkan bahwa sebagian besar responden baik yang tidak mengalami keluhan nyeri $(56 \%)$ maupun responden dengan keluhan nyeri neuropatik (67\%) mengalami insomnia, sedangkan responden dengan keluhan nyeri lokal sebagian besar tidak mengalami insomnia (56\%). Hasil ini tidak sejalan dengan penelitian Hananta et al. (2014) yang medapatkan hasil bahwa penderita kanker payudara yang mengalami nyeri maupun tidak sebagian besar mengalami gangguan tidur, karena nyeri memiliki pengaruh 3,9 kali lipat lebih banyak pada gangguan tidur dibandingkan dengan tidak ada nyeri dengan menurunkan waktu tidur dan meningkatkan kecemasan pada 
penderita kanker payudara. Perbedaan ini dapat disebabkan oleh tingkat keparahan dan luas penyebaran nyeri pasien yang berpengaruh secara langsung dengan insomnia yang dialaminya (Dragioti et al., 2014).

\section{SIMPULAN}

Simpulan dari penelitian ini adalah penderita kanker payudara yang sedang menjalani kemoterapi di RSUD Abdul Wahab Sjahranie Samarinda pada Juli 2019 sebagian besar mengalami insomnia berusia $\geq 50$ tahun, tidak memiliki pekerjaan, seluruhnya sudah menikah, memiliki insomnia ringan dengan lebih dari 1 jenis keluhan insomnia, serta dialami oleh yang tidak memiliki keluhan nyeri maupun memiliki keluhan nyeri neuropatik.

\section{DAFTAR PUSTAKA}

Alifiyanti, D. H. (2017). Kualitas Tidur Pasien Kanker Payudara Berdasarkan Terapi yang Diberikan di RSUP DR. Hasan Sadikin Bandung. Jurnal Pendidikan Keperawatan Indonesia, hal. 115-125.

Berk, M. (2009). Sleep and depression-theory and practice. Australian family physician, 38(5), hal. 302-304.

Bragantini, D., Sivertsen, B., Gehrman, P. Lydersen, S., \& Güzey, I. C. (2019). Variations in circadian genes and individual nocturnal symptoms of insomnia: The Hunt Study. Chronobiology International: The Journal of Biological and Medical Rhytm Research, 36(5), hal 681-688.
Costa, A. R., Fontes, F., Pereira, S., Gonçalves, M., Azevedo, A., \& Lunet, N. (2014). Impact of breast cancer treatments on sleep disturbances-A systematic review. The Breast, 23(6), 697709.

Costa, W. A., Monteiro, M. N., Queiroz, J. F., \& Gonçalves, A. K. (2017). Pain and quality of life in breast cancer patients. Clinics (Sao Paulo, Brazil), 72(12), hal. 758-763.

Deguchi, Y., Iwasaki, S., Ishimoto, H., Ogawa, K., Fukuda, Y., Nitta, T., ... \& Inoue, K. (2017). Relationships between temperaments, occupational stress, and insomnia among Japanese workers. PloS one, 12(4), e0175346.

Dragioti, E., Levin, L. Å., Bernfort, L., Larsson, B., \& Gerdle, B. (2017). Insomnia severity and its relationship with demographics, pain features, anxiety, and depression in older adults with and without pain: cross-sectional population-based results from the PainS65+ cohort. Annuals of general psychiatry, 16(1), hal. 15.

Fakih, R., Rahal, M., Hilal, L., Hamieh, L., Dany, M., Karam, S., ... \& Assi, H. (2018). Prevalence and severity of sleep disturbances among patients with early breast Cancer. Indian journal of palliative care, 24(1), hal. 35.

Fang, H. F., Miao, N. F., Chen, C. D., Sithole, T., \& Chung, M. H. (2015). Risk of cancer in patients with insomnia, parasomnia, and obstructive sleep apnea: a nationwide nested case-control

*Corresponding Author :

Rohadatul Aisy

Program Studi Kedokteran, Fakultas Kedokteran

Universitas Mulawarman

Email : Rohadatul Aisy@gmail.com 
study. Journal of Cancer, 6(11), hal. 1140.

Grewal, R. G. (2017). Epidemiology of Insomnia. In Hrayr P. A., Current Clinical Neurology: Clinical Handbook of Insomnia. Switzerland: Springer International Publishing, hal. 1325.

Hananta, L., Benita, S., Barus, J., \& Halim, F. (2014). Gangguan Tidur pada Pasien Kanker Payudara di Rumah Sakit Dharmais Jakarta. Damianus Journal of Medicine, 13(2), hal. 84-94.

Hoang, H. T. X., Molassiotis, A., Chan, C. W., \& Nguyen, T. H. (2019). New-onset insomnia among cancer patients undergoing chemotherapy: prevalence, risk factors, and its correlation with other symptoms. Sleep and Breathing, hal. 1-11.

Kementerian Kesehatan Republik Indonesia. (2018). Kemenkes Berhasil Deteksi Dini Kanker 3 Juta Perempuan. Retrieved February 3rd 2019, from http://www/depkes.go.id/article/vi ew/1400001/kemenkes-berhasildeteksi-dini-kanker-3-jutaperempuan.html

Komite Penanggulangan Kanker Nasional. (2017). Pedoman Nasional Pelayanan Kedokteran Kanker Payudara. Jakarta: Kementerian Kesehatan Republik Indonesia.

Kumar, S., Kumari, A., Manasa, R. V., Das, S. C., \& Ghoshal, V. (2018). Insomnia among Attendants of Patients in a Tertiary
Care Hospital at

Visakhapatnam. Community

Med, 9(9), hal. 709-713.

Lind, M. J., \& Gehrman, P.R. (2016). Genetic pathways to insomnia. Brain Sci. 6(4):64.

Maeda, M., Filomeno, R., Kawata, Y., Sato, T., Maruyama, K., Wada, H., ... \& Tanigawa, T. (2019). Association between unemployment and insomniarelated symptoms based on the Comprehensive Survey of Living Conditions: a large cross-sectional Japanese population survey. Industrial health, hal. 2018-0031.

McGinty, H.L., Carroll, A.J., Sanford, S.D. (2017). Sleep Disturbance in Cancer Survivors. In Hrayr P. A, Current Clinical Neurology : Clinical Handbook of Insomnia 3rd Ed. Switzerland: Springer International Publishing, hal. 221242.

Mercadante, S., Girelli, D., \& Casuccio, A. (2004). Sleep disorders in advanced cancer patients: prevalence and factors associated. Supportive Care in Cancer, 12(5), hal. 355-359.

Paul, R., \& Anafi, R. (2017). Insomnia in Patients with Comorbid medical Problems. In In Hrayr P. A., Current Clinical Neurology : Clinical Handbook of Insomnia 3rd Ed. Switzerland: Springer International Publishing, hal. 199219.

Peltzer, K., \& Pengpid, S. (2019). Prevalence, social, and health correlates of insomnia among Persons 15 years and older in

*Corresponding Author :

Rohadatul Aisy

Program Studi Kedokteran, Fakultas Kedokteran

Universitas Mulawarman

Email : Rohadatul Aisy@gmail.com 
Indonesia. Journal of Psychology, Health \& Medicine, hal. 1-12.

Pigeon, W.R., \& Grandner, M. A. (2013). Creating an Optimal Sleep Environment. In Clete A. K., Encyclopedia of Sleep 1st Ed. Cambridge: Elsevier, hal. 72-76.

Pratiwi, W. (2016). Hubungan Derajat Insomnia dengan Konsentrasi Belajar Mahasiswa Program Studi IImu Keperawatan Universitas Muhammadiyah Yogyakarta. Yogyakarta: UMY Repository.

Riemann, D., Nissen, C., Palagini, L., Otte, A., Perlis, M. L., \& Spiegelhalder, K. (2015). The neurobiology, investigation, and treatment of chronic insomnia. The Lancet Neurology, 14(5), hal. 547-558.

Sadock, B. J., Sadock, V. A., \& Ruiz, P. (2017). Kaplan \& Sadock's Comprehensive Textbook of Psychiatry 10th Ed. Philadelphia: Wolters Kluwer, hal. 337-351.

Sadock, B. J., Ahmad, S., \& Sadock, V. A. (2019). Kaplan \& Sadock's Pocket Handbook of Clinical Psychiatry 6th Ed. Philadelphia: Wolters Kluwer, hal. 337-351.

Silvestri, R. (2017). Sleep in Older Adults. In Sudhansu C. \& Luigi F. S., Oxford Textbook of Sleep Disorders. New York: Oxford University Press, hal. 469-474.

Taylor, D., Gehrman, P., Dautovich, N., Lichstein, K., \& McCrae, C. (2014). Handbook of Insomnia. London: Springer Healthcare.

World Health Organization. (2018). Breast Cancer. Retrieved

*Corresponding Author :

Rohadatul Aisy

Program Studi Kedokteran, Fakultas Kedokteran Universitas Mulawarman

Email : Rohadatul Aisy@gmail.com
February 3rd 2019, from https://who/int/cancer/prevention/ diagnosis-screening/breastcancer/en/

Yudiyanta. (2017). Pengkajian Nyeri. In Bambang S. S., Lucas M., Sudadi, Buku Ajar Nyeri 2017. Yogyakarta: Perkumpulan Nyeri Insonesia, hal. 103-127. 